Global Conferences Series:

Social Sciences, Education and Humanities (GCSSSEH), Volume 3, 2019

The $1^{\text {st }}$ International Conference on Education, Social Sciences and Humanities

DOI: https://doi.org/10.326/hum0197

\title{
The Development and Validation of the Thesis-Writing Procrastination Scale
}

\section{Diniy Hidayatur Rahman}

Universitas Negeri Malang

(*) $\square$ diniy.hidayatur.fip@um.ac.id

\begin{abstract}
Several studies found that thesis-writing procrastination is one of the greatest factors causing delays in the graduation of undergraduate students. However, there are no assessment tools that can measure the procrastination in the context of thesis writing specifically. Therefore, the purpose of the research is to develop and validate an instrument named the Thesis-Writing Procrastination Scale (TW-PS). The scale was developed through four procedures: (1) defining the construct; (2) developing the measurement model; (3) performing confirmatory factor analysis; and (4) examining the validity of the measurement model. 200 randomly selected subjects participated in the research. To test the TW-PS's validity and reliability, the research performed exploratory and confirmatory factor analysis and the Alpha Cronbach. The procedures successfully validated 10 items and eliminated the other four.
\end{abstract}

Keywords: procrastination; thesis writing; assessment

\section{Introduction}

Thesis-writing procrastination occurs frequently in Indonesian universities. Wicaksana (2014) found that $67.5 \%$ of undergraduate students in his research delayed their thesis writing. A similar result also found by Husnia (2015) in her study on students in Faculty of Psychology Universitas Islam Negeri Maulana Malik Ibrahim. In the study, 10.5\% of the subjects procrastinated their thesis writing at a high level and another $86.9 \%$ at a moderate level. Habibah (2017) also found that $10 \%$ of her subjects delayed their thesis writing at a high level and another $45 \%$ at a moderate level.

In line with the findings, thesis-writing procrastination is one of the greatest contributing factors to the delay of the students' graduation. Data taken from the ICT Center of Universitas Negeri Malang (UM) in January 2018 showed that there were 3,749 (12.66\%) out of 29,613 undergraduate students at the university who can not complete their study in timely manner. A preliminary survey conducted randomly on 150 of them showed that $96 \%$ of them graduated lately due to the delayed completion of their thesis. Another study conducted by Hamid (2015) at IAIN Antasari Banjarmasin also showed that the thesis-writing procrastination was one of the reasons for the delay in students' graduation. Similar result was also shown at Faculty of Psychology Universitas Surabaya (Putri \& Savira, 2013).

Thesis-writing procrastination is a problem that needs to be addressed immediately. This is because it is a loss for the students, the supervisors, and the university. For the students, the procrastination means a delay for the graduation. That way, they will lose the opportunity to work or 
pursue a higher level of study. For the supervisors, the late students will be an academic burden for them. Their task will be even greater in the following semesters because they will be tasked with supervising other students theses. The more students are late in graduation, the more time, thought, and energy they have to spend in supervising. For the university, the delay will worsen the level of accreditation. The more students are late in graduation, the lower the level of the university accreditation.

Unfortunately, there are no assessment tools that can measure the procrastination in the context of thesis writing specifically. The existing procrastination scales only measure the procrastination in the general academic context. Therefore, using them in the context of thesis writing is not really appropriate. Some of them are: (1) Procrastination Assessment Scale-Students (PASS) developed by Solomon \& Rothblum (1984); (2) Tuckman Procrastination Questionnaire (TPQ) developed by Tuckman (1991); and (3) Academic Procrastination Scale (APS) developed by McCloskey \& Scielzo (2015). These scales are widely used in various research and counseling/psychotherapy services and have adequate psychometric eligibility in their own respective contexts. However, because of the general academic context they use, measuring procrastination in thesis writing context with these scales is not really right.

The term procrastination comes from Latin pro which means forward and crastinus which means belonging to tomorrow. This term refers to individual behavior to postpone doing important and urgent things that can actually be carried out right now (Knaus, 2010: xvi). The term began to emerge and was regarded as a problem in modern society, especially in industrial societies, where people were pursued by targets, in the form of time and products with certain quantitative and qualitative standards. The agrarian society that lived in the earlier era did not always consider the procrastination as a problem. Some of them even consider it as a pearl of wisdom (Ferrari, Johnson, \& McCown, 1995: 3-5). Ancient Egyptian society, for example, sometimes considers the procrastination as a positive thing because it avoids them from unnecessary activities and impulsive efforts (Burka \& Yuen, 2008: 6).

Although experts and researchers agree on delaying behavior as a major factor in defining procrastination, they differ on several details. Schraw et al. (2007) state that a delay can be called procrastination if the procrastinator does it intentionally with an understanding that the delayed thing must be completed at that time. To call a delay as procrastination, Solomon \& Rothblum (1984) also require a consistency. In other words, the delay made only once or at a fraction of time can not be called procrastination. Furthermore, Ferrari et al. (1995) stated that procrastination does not always cause poor result or performance. Some people work at the last moment to increase their motivation and fighting power so that they can produce standardized work or performance. Therefore, the results achieved can not be a measure of whether a delay is called procrastination or not. Based on the above definitions, it can be argued that procrastination is a delay in starting and or completing important tasks that are carried out consistently without justifiable reasons.

In the educational context, the behavior of postponing doing academic tasks is known as academic procrastination. Solomon \& Rothblum (1984) define academic procrastination as a tendency to respond to academic tasks that must be completed at the time by intentionally delaying starting or completing them by carrying out other activities not needed or even not related to the tasks. Solomon \& Rothblum (1984) said that there are six academic areas that students postpone frequently: (1) writing a term paper; (2) studying for exams; (3) reading weekly assignments; (4) attendance tasks; (5) administrative tasks supporting the learning; and (6) academic activities in general. Among the six, writing a term paper is the most frequently delayed task. Based on the above literature review, it can be concluded that the thesis-writing procrastination is the students tendency to consistently delay starting and or completing their thesis by intentionally carrying out other activities that are not needed or not even related to the completion of the thesis. Based on this definition, delaying thesis writing can be called procrastination if it: (1) is done consciously with the understanding that the 
thesis must be completed timely, so that the delay will be considered as a problem; (2) is carried out repeatedly with high frequency; and (3) is postponed by prioritizing other activities that are not needed or not even related to the completion of the thesis.

Based on the discussed background above, this study aims to develop a scale called the ThesisWriting Procrastination Scale (TW-PS). This scale will be constructed based on two indicators of procrastination: frequency of delay and the level of problem (Solomon \& Rothblum, 1984). Frequency of delay refers to the level of frequency in delaying a particular task, while level of problem refers to the procrastinator's awareness that the delay is a problem or not for him/her. In order to measure the procrastination in thesis writing context specifically, the items of TW-PS will be constructed from the two indicators with the context of six main activities in thesis writing: (1) finding references for the thesis; (2) reading materials for the thesis; (3) writing the thesis (4) conducting field research; (5) discussing the result of the research with friends; (6) consulting the thesis with the supervisor; and (6) revising the thesis (Rahman, 2018: 23). Through this development process, it is expected that the TWPS will meet the criteria as an innovative scale, which means that: (1) it contains no more than 15 items so that it can efficiently measure the procrastination; and (2) it has adequate psychometric eligibility.

\section{Method}

The study applies research and development design which will construct a scale called ThesisWriting Procrastination Scale (TW-PS). To develop the scale, the study follows the procedures recommended by Hair, et al. (2006: 779-800) consisting of: (1) defining the construct underlying the scale; (2) developing the construct measurement model; (3) conducting confirmatory factor analysis to empirically evaluate whether the developed construct confirms the theory or not; and (4) evaluating the validity of the measurement model compiled in procedures 2 and 3. This step will revise the items and or indicators that have been developed in procedure 1.

200 undergraduate students of Universitas Negeri Malang (UM) writing their thesis participate in the study. The number is obtained by multistage cluster sampling technique. First, the researcher identified the number of students writing the thesis in eight faculties at UM (Faculty of Education, Faculty of Economics, Faculty of Letter, Faculty of Engineering, Faculty of Mathematics and Science, Faculty of Sports Science, Faculty of Social Science, and Faculty of Psychology). Next, based on the subjects grouping according to their faculties, $25 \%$ of departments from each faculty are randomly chosen as representatives of the faculties. Finally, the researcher selects randomly 200 students writing the thesis in the representative departments to determine the final sample. Selected subjects are then contacted by telephone or email to fill out the online or offline TW-PS prototype scale. If a subject is not willing to participate, another subject from the same department will be randomly selected.

The construct validity of the scale will be evaluated by the exploratory factor analysis. This analysis begins by checking KMO-MSA to check the eligibility of all items. If the KMO-MSA value is $\geq 0.5$ with $\mathrm{p} \leq 0,05$, the analysis can be continued. In addition, if the value of the MSA for a particular item is $\geq 0.5$, it can go for further analysis. Conversely, if the MSA for the item is $<0.5$, it must be discarded. The next step is extracting the eligible items with the varimax method. The item that has a loading of $\geq 0.5$ for an indicator will be regarded as a good item. However, the item will be regarded as not meeting the theoretical assumptions if it is extracted into an incorrect indicator. Thus, the item must be discarded even though it has a loading of $\geq 0.5$ statistically. Furthermore, indicators that have a loading of $\geq 0.5$ for a developed construct will be determined as an eligible indicator. This exploratory factor analysis will be performed by using SPSS 20. Valid items and indicators based on the exploratory factor analysis will then be tested for their reliability with the Alpha Cronbach. The coefficient of the Alpha Cronbach used in the study is $>0.7$. The analysis will also be performed by 
using SPSS 20. The next is performing confirmatory factor analysis (CFA) with a second order technique. The analysis will be used to test the unidimensionality of the TW-PS. In this study, it will be determined by the value of RMSEA $\geq 0.08$. The validity of an item for an indicator and an indicator for a construct will be determined by the Lambda value $\geq 0.4$. This CFA will be performed by using the Student Version of Lisrel 8.80.

\section{Results and Discussion}

The Initial Blueprint of TW-PS

Based on a review of the academic procrastination construct proposed by Solomon \& Rothblum (1984) and the results of a preliminary study on the context of thesis writing, the researcher constructed 14 items of TW-PS extracted from two indicators. Detailed descriptions of subvariables, indicators, and items are displayed in table 1. Four Likert answer choices are provided for each of these items, ranging from never to always.

The Result of Exploratory Factor Analysis, Alpha Cronbach, and Confirmatory Factor Analysis

The exploratory factor analysis of 14 items of TW-PS shows that the ten of them have a loading factor of $\geq 0.5$, while the other four (items $11,12,13$, and 14 ) have a loading factor of $<0.5$. Thus, the ten can be categorized as valid items, while the rests are invalid. Likewise, both TW-PS indicators have a loading factor of 0.863 . Thus, the two indicators have a high loading factor on the Thesis-Writing Procrastination variable. In accordance with the initial blueprint of TW-PS, the ten valid items are grouped into two indicators. Items 1, 3, 5, 7 and 9 are grouped in the indicator of Frequency of Delay, while items 2, 4, 6, 8 and 10 are grouped in the indicator of Level of Problem. Alpha Cronbach analysis is then performed on the 10 to evaluate their reliability. The result shows that the items are completely reliable since they have the Alpha Cronbach coefficient of $>0.7$. The detail results are summarized in table 2 .

The items are then further tested by confirmatory factor analysis to evaluate the unidimensionality of the measurement model and the validity of each item. The details of the results are shown in table 2. It can be seen in table 2 that the RMSEA is 0.050 which means that the measurement model is good. The value of Chi-Square is 177.53 with a probability of 0.07235 which means that the measurement model has obtained adequate empirical support. Furthermore, The Lambda of all items and indicators is $>0.4$, which means that the items and indicators are valid.

\section{Conclusions}

The development and validation process of the TW-PS has produced 10 valid and reliable items and eliminated the other four that do not meet the requirements. These items are only intended to measure the level of procrastination in the context of thesis writing but not other contexts. Thus, the score that will be resulted is the total score of procrastination in thesis writing. The higher the score, the higher the procrastination tendency of the subject. On the contrary, the lower the score the lower the procrastination tendency. Compared to similar instruments, the TW-PS has several advantages: (1) it only contains 10 items so that it is very efficient to use; and (2) it is very appropriate to be used in counseling setting or mapping specific procrastination problems in thesis writing. One of the disadvantages of the TW-PS is the number and homogeneity of the samples used in the development process. This sample problem limits the use of the TW-PS only to the population of subjects involved.

\section{Acknowledgments}


I would like to express my gratitude to Dra. Ella Faridati Zen, M.Pd, the Head of Pusat Pengembangan Bimbingan dan Konseling Mahasiswa (Students Counseling Center) at Universitas Negeri Malang, which facilitated the research process from the identification of subjects to data collection. Without her help and facilitation, I would experience many administrative difficulties which might frustrate the research.

Table 1. Initial Blueprint of TW-PS

\begin{tabular}{|c|c|c|}
\hline Variable & Indicators & Items \\
\hline \multirow{14}{*}{$\begin{array}{l}\text { Thesis- } \\
\text { Writing } \\
\text { Procras- } \\
\text { tination }\end{array}$} & \multirow{7}{*}{$\begin{array}{l}\text { Frequency } \\
\text { of Delay in } \\
\text { Thesis } \\
\text { Writing }\end{array}$} & $\begin{array}{l}\text { 1. Saya menunda-nunda untuk mencari referensi/bahan pustaka terkait penulisan } \\
\text { skripsi (I procrastinate to find references) }\end{array}$ \\
\hline & & $\begin{array}{l}\text { 3. Saya menunda-nunda untuk membaca referensi/bahan pustaka terkait penulisan } \\
\text { skripsi (I procrastinate to read materials for my thesis references) }\end{array}$ \\
\hline & & 5. Saya menunda-nunda untuk menulis bab-bab skripsi (I delay to write my thesis) \\
\hline & & $\begin{array}{l}\text { 7. Saya menunda-nunda turun ke lapangan untuk melakukan penelitian (I postpone } \\
\text { conducting field research) }\end{array}$ \\
\hline & & $\begin{array}{l}\text { 9. Saya menunda-nunda untuk mendiskusikan skripsi saya dengan pihak ketiga (selain } \\
\text { dosen pembimbing) (I delay to discuss the result of my research with friend(s)) }\end{array}$ \\
\hline & & $\begin{array}{l}\text { 11. Saya menunda-nunda untuk mengkonsultasikan skripsi saya pada dosen } \\
\text { pembimbing (I delay to consult my thesis with the supervisor(s)) }\end{array}$ \\
\hline & & $\begin{array}{l}\text { 13. Saya menunda-nunda untuk merevisi skripsi saya (I postpone revising my } \\
\text { thesis) }\end{array}$ \\
\hline & \multirow{7}{*}{$\begin{array}{l}\text { Level of } \\
\text { Problem } \\
\text { in Thesis- } \\
\text { Writing } \\
\text { Delay }\end{array}$} & $\begin{array}{l}\text { 2. Penundaan dalam mencari referensi/bahan pustaka tersebut merupakan masalah } \\
\text { bagi saya (It is a problem for me that I procrastinate to find references) }\end{array}$ \\
\hline & & $\begin{array}{l}\text { 4. Penundaan dalam membaca referensi/bahan pustaka tersebut merupakan masalah } \\
\text { bagi saya (It is a problem for me that I procrastinate to read materials for my } \\
\text { thesis references) }\end{array}$ \\
\hline & & $\begin{array}{l}\text { 6. Penundaan dalam menulis bab-bab skripsi tersebut merupakan masalah bagi saya (It } \\
\text { is a problem for me that I delay to write my thesis) }\end{array}$ \\
\hline & & $\begin{array}{l}\text { 8. Penundaan dalam melakukan penelitian lapangan tersebut merupakan masalah bagi } \\
\text { saya (It is a problem for me that I postpone conducting field research) }\end{array}$ \\
\hline & & $\begin{array}{l}\text { 10. Penundaan dalam berdiskusi dengan pihak ketiga tersebut merupakan masalah bagi } \\
\text { saya (It is a problem for me that I delay to discuss my research result with } \\
\text { friend(s)) }\end{array}$ \\
\hline & & $\begin{array}{l}\text { 12. Penundaan dalam berkonsultasi dengan dosen pembimbing tersebut merupakan } \\
\text { masalah bagi saya (It is a problem for me that I delay to consult my thesis with } \\
\text { the supervisor(s)) }\end{array}$ \\
\hline & & $\begin{array}{l}\text { 14. Penundaan dalam merevisi skripsi tersebut merupakan masalah bagi saya (It is a } \\
\text { problem for me that I postpone revising my thesis) }\end{array}$ \\
\hline
\end{tabular}

Table 2. The Result of EFA, Alpha Cronbach Analysis, and CFA

\begin{tabular}{|c|c|c|c|c|c|c|c|c|}
\hline Indicators & $\begin{array}{c}\text { Item } \\
\text { Grouping }\end{array}$ & $\begin{array}{l}\text { Loading } \\
\text { Factor }\end{array}$ & $\begin{array}{c}\text { Alpha } \\
\text { Cronbach }\end{array}$ & $\begin{array}{c}\text { Corrected } \\
\text { Item-Total } \\
\text { Correlation }\end{array}$ & Lambda & RMSEA & $\begin{array}{c}\text { Chi- } \\
\text { Square }\end{array}$ & $p$ \\
\hline \multirow{5}{*}{$\begin{array}{l}\text { Frequency of } \\
\text { Thesis-Writing } \\
\text { Procrastination } \\
\text { (Loading Factor }=0,863 \text {; } \\
\text { Lambda }=0,84 \text { ) }\end{array}$} & 1 & 0,746 & \multirow{6}{*}{0,906} & 0,892 & 0,52 & \multirow{6}{*}{0,050} & \multirow{6}{*}{177,53} & \multirow{6}{*}{0,07235} \\
\hline & 3 & 0,795 & & 0,890 & 0,60 & & & \\
\hline & 5 & 0,789 & & 0,894 & 0,62 & & & \\
\hline & 7 & 0,882 & & 0,897 & 0,58 & & & \\
\hline & 9 & 0,788 & & 0,899 & 0,54 & & & \\
\hline Degree of Problem & 2 & 0,603 & & 0,897 & 0,51 & & & \\
\hline
\end{tabular}




\begin{tabular}{|c|c|c|c|c|c|c|c|c|}
\hline Indicators & $\begin{array}{c}\text { Item } \\
\text { Grouping }\end{array}$ & $\begin{array}{l}\text { Loading } \\
\text { Factor }\end{array}$ & $\begin{array}{c}\text { Alpha } \\
\text { Cronbach }\end{array}$ & $\begin{array}{c}\text { Corrected } \\
\text { Item-Total } \\
\text { Correlation }\end{array}$ & Lambda & RMSEA & $\begin{array}{l}\text { Chi- } \\
\text { Square }\end{array}$ & $p$ \\
\hline \multirow{4}{*}{$\begin{array}{l}\text { in Thesis-Writing } \\
\text { Procrastination } \\
\text { (Loading Factor = 0,863; } \\
\text { Lambda }=0,76 \text { ) }\end{array}$} & 4 & 0,806 & & 0,897 & 0,66 & & & \\
\hline & 6 & 0,878 & & 0,899 & 0,56 & & & \\
\hline & 8 & 0,735 & & 0,901 & 0,58 & & & \\
\hline & 10 & 0,708 & & 0,896 & 0,62 & & & \\
\hline
\end{tabular}

\section{References}

Burka, J. B. \& Yuen, L. M. (2008). Procrastination: Why You Do It, What To Do About It Now. Cambridge: Da Capo Press.

Ferrari, J. R., Johnson, J. L., \& McCown, W. G. (1995). Procrastination and Task Avoidance: Theory, Research, and Treatment. New York: Springer.

Habibah, D. P. N. (2017). Hubungan antara kematangan emosi dengan prokrastinasi dalam penyusunan skripsi mahasiswa Fakultas Psikologi Universitas Muhammadiyah Surakarta. (Unpublished undergraduate thesis) Universitas Muhammadiyah Surakarta, Surakarta, Indonesia.

Hair, J. F. J., Black, W. C., Babin, B. J., Anderson, R. E., \& Tatham, R. L. (2006). Multivariate Data Analysis (6 $6^{\text {th }}$ Edition). New Jersey: Prentice Hall.

Hamid, R. (2015). Penyebab keterlambatan mahasiswa menyelesaikan studi S1 di IAIN Antasari Banjarmasin. (Unpublished research). Institut Agama Islam Negeri Antasari, Banjarmasin, Indonesia.

Husnia, D. (2015). Hubungan prokrastinasi akademik terhadap tingkat kecemasan pada mahasiswa Psikologi angkatan 2011 UIN Maulana Malik Ibrahim Malang. (Unpublished undergraduate thesis) Universitas Islam Negeri Maulana Malik Ibrahim, Malang, Indonesia.

Knaus, W. (2010). End Procrastination Now! Get It Done with a Proven Psychological Approach. New York: McGraw-Hill.

McCloskey, J. \& Scielzo, S. A. 2015. Finally!: The Development and Validation of the Academic Procrastination Scale. Research Gate. DOI: 10.13140/RG.2.2.23164.64640.

Putri, D. K. S. \& Savira, S. I. (2013). Pengalaman menyelesaikan skripsi: studi fenomenologis pada mahasiswa Psikologi Universitas Negeri Surabaya. Character, 2(2), 1-14.

Rahman, D. H. (2018). Model hubungan faktor-faktor yang mempengaruhi prokrastinasi penyelesaian skripsi dalam perspektif Rational Emotive Behavior Therapy. (Unpublished doctoral dissertation) Universitas Negeri Malang, Malang, Indonesia.

Schraw, G., Wadkins, T., \& Olafson, L. (2007). Doing the things we do: a grounded theory of academic procrastination. Journal of Educational Psychology, 99(1), 12-25.

Solomon, L. J. \& Rothblum, E. D. (1984). Academic procrastination: frequency and cognitive behavior correlation. Journal of Counseling Psychology, 31, 304-510.

Tuckman, B. W. (1991). The development and concurrent validity of the Procrastination Scale. Educational and Psychological Measurement, 51, 473-480.

Wicaksana, B. (2014). Hubungan antara regulasi diri dengan prokrastinasi tugas akhir skripsi pada mahasiswa Prodi BK UNY. (Unpublished undergraduate thesis) Universitas Negeri Yogyakarta, Yogyakarta, Indonesia. 